\title{
Awareness of Students on the Usefulness of ICT Tools in Education: Case of EMU
}

\author{
Ilodigwe Udoka Tochukwu ${ }^{1}$, Fatma Tansu Hocanın ${ }^{2}$ \\ ${ }^{I}$ (Department of Management Information Science, Cyprus International University, TRNC) ${ }^{2}$ (Department of \\ Computer Education and Instructional Technologies, Eastern Mediterranean University, TRNC)
}

\begin{abstract}
The importance of technology and its adoption has widely turned out to be a norm in the conventional classroom for both teachers and learners. Preliminary researches have shown that educational institutions have adopted Information Communication Technology (ICT) in their teaching/learning process. There are many researches that have been conducted to find out the level of students' awareness on the use of ICT tools, and the factors affecting ICT diffusion on the part of the students' education. The study was conducted at the Information Technology (IT) Department of Eastern Mediterranean University (EMU) in Northern Cyprus. The significance of this research focused on investigating EMU IT students' awareness on the use of ICT tools in education by considering factors like skills in usage of ICT tools, purpose of usage etc., based on various variables like age, gender and class levels of the participants. The study also elaborates the basic trends of ICT, and the sync between ICT and education for pedagogical development. Data were elicited from 120 participants through the use of a questionnaire containing 54 ICT related questions and five openended interview questions. The analyses showed that there is a significant difference between male and female respondents on their awareness of the use of ICT tools, where female students proved to be more active on the adoption of such tools. In addition, a significant difference was also observed between students' age where the younger students displayed to be more active in the usage of such ICT tool.
\end{abstract}

Keywords: Instructional Technology, Information Communication Technology, awareness, ICT tools

\section{Introduction}

Constructivism as a learning theory posits that experience and knowledge is built and constructed by the learner on the basis of a mental activity. Students are proven to be lively species looking for definitions and meaning. This theory increases learner's rational and theoretical development. The essential idea of constructivism learning principle is the part that knowledge or interaction with the connecting surrounding performs in learner training. Social constructivism inspires students to reach at their description of what is true, subjective at their upbringing beliefs or rooted general view. Past growths and sign methods, like semantic, logic and reasoning, and calculative systems are embedded within student as a participant of a specific culture and beliefs, and all of these are assimilated all through the life of the student. This focuses on the aim of nature of the student's public connection with information and communication technological (ICT) tools, instructional materials and also with the experienced associates of the public.

Some scholastic technologists which use most type of constructivist standpoint likewise rely on collaborative learning. Presently, on the part of education, constructivism has occupied a dominant lead role on which the aim of investigators have deviated into finding how experience is constructed. Looking at the development of ICT learning tool, constructivist learning theories have been studied and reviewed as instructors try to include ICT even though trying to harmonize constructivist centered educations. Nowadays, digital populations go across to virtual worlds in which the ICT tools are started to be accepted as an instrument in learning. According to [1], the vast amount of information that ICT supply on a daily basis has allowed students new ways to explore education compared to ordinary instructional tools.

ICT is mostly presumed to be a platform and catalyst of trending educational change [1]. Instructional technology arranges a learner through assisting them to gather an insightful comprehension and familiarity of learning resource, ways for investigating via research study, principles, design, assessment, and utilization. Instructional technology target is on the successful patterns to encourage learning by adopting technologies and imparting the usefulness of technological tools on learners and institutions. As ICT tools turn out to be obvious, learning became the center of all kinds of teaching processes [2], [3]. It is common today that technology welcomes learners as they take a walk into modern classroom which are donated with ICT tools like Liquid Content Display (LCD) projectors, computer software programs, interactive whiteboards, etc. Regrettably, the presence of ICT tools does not necessarily mean its effectiveness [4]. Therefore, this study focuses on investigating the perception of EMU IT students' on the effectiveness of use of ICT tools in teaching and learning settings. Educational technological tools is most times seen as a booster for modification, alteration in teaching patterns, modification in integration processes and in retrieval of information or data [5]. ICT tools 
have also helped learning processes with their various features as it has revealed learning through communication, sharing, web technologies, etc. in which this allows for active learning via all senses.

Most learners generally support the use of technology in classrooms in which [6] investigated learner's perception in relation to ICT educational tools. They discovered that learners' perception on the ICT tools has been useful and inspiring to education process. Furthermore, various learners in the study perceived ICT tools as an essential part of their learning process.

\subsection{Problem Statement}

New ICT tools generate excitement and fun and also worries and concerns. Since huge value of time, money and effort is put in into these ICT tools, it therefore should display educational value for learners, so as to justify its cost and worth. ICT as a term has been largely investigated on. Nevertheless, since it is largely used, it has not been broadly studied. In as much as these ICT tools are growingly available in the traditional classroom settings, knowing learners awareness of ICT tools at the undergraduate level is relevant, as this will enable the instructors in education to properly ascertain the necessary technological tool to adopt when preparing the lesson content and resources to teach.

Learners are said to be the central focus at the thought of establishing an institution for learning, and these contemporary students are almost skilled at the usage of certain ICT tools even before the entrance of certain colleges or institutions. It is therefore, very necessary to make ready those basic ICT tools which should be adopted by such learner on the entrance of such colleges or institutions. For this reason, it will be a problem if these students awareness, attitudes, thoughts, skills, motivational factors and their ease of use is not determined at the initial stage before establishing a school, employing an instructor, building a curriculum, preparing an instructional material or course objectives and further evaluating of the entire teaching and learning processes. ICT importance is very glaring from the educational approach. ICT adoption in classroom settings provides numerous usefulness since it builds a quality learning surroundings [6]. ICT has effects on learning through ensuring numerous types of interactions. The conventional classroom setting migrated from an instructor-centered to a student-centered, and the learner turns from being a listener to being a collaborator Moreover, ICT educational tools engage learners to higher level cognitive tasks. This is done via problem solving techniques and real-world projects. In [8], it is posited that the recent information insurgency and growing effect of ICT have remodeled the approaches of education and research in some institutions.

These remains the problem that this research work will further look into, because the information gathered will be valuable for administrators, educational planners, individual teachers, parents and guardians, counsellors and government ministries. For if the awareness of these learners are further identified, then it becomes easier to identify the basic ICT tools preferred by students and their levels of skills at them; without this, then it remains a problem to be tackled in the general education system. In [9], it is stated that even though ICT adoption have grown, most schools never had broad institutional visions or strategies on ICT adoption.

\subsection{Aim of the Study}

The main aim of this study is to examine the awareness of IT students in EMU on the effectiveness of ICT tools usage in enhancing learning, according to their age, gender and class. The study will be discussed by using the research questions mentioned below:

a. What are the percentage and significant level of skills and the level of purpose on the use of ICT tools by EMU undergraduate IT students?

b. Is there any significant difference on the awareness level on the use of ICT tools by EMU undergraduate IT students according to their gender, age and class level?

c. What is the awareness level of EMU undergraduate IT students on usefulness of ICT tools in their learning process according to their gender and class level?

Considering the increment of ICT tools is therefore important to carry out a quantitative and qualitative research on its value in teaching and learning process. It is vital to investigate student's perception of ICT tool's importance and hindrances at the undergraduate level, and this research will cover this end. The perceived importance of ICT tools must be analyzed; when learners do not identify value in ICT usage, then ICT adoption may be looked into or instructors might require training and re-training on its use. From this study, the reader will understand the importance of placement in education as it tends to be a problem for it is very important to be able to determine student awareness level according to their age, class and gender. It is proper to rightly determine if the ICT usage has been affected by age, class or gender of a particular learner, because this will further enable the proper placement of a particular learner to the right class for easy ICT usage during class activities and teaching and learning process, without which remains a problems. Furthermore, adding to the investigation of perceived effectiveness of ICT tools by students, levels of great enhancement were determined also from the learners. It is obvious from other researches that ICT tools are not always adopted effectively [10]. In most cases learners can perceive this and generate constructive feedback. 


\section{Literature Review}

Acquiring education leads continuous increment and dynamism to community via the adoption of technologies. Instructional technological tools are adopted by teachers in designing instructional materials and operated by students in connecting with other learners; and also the instructor together, for purposefully achieving learning objectives. In this area of study, instructional technology focuses interaction skill and educational theories via the effective adoption and inclusion of various technological media [11]; further explains ICT in learning as a paradigm in education that gives learners ability to pass on ideas and views in a more recent and novel way which would in any way be inefficient or ineffective with the use of other instructional methods. That is to say, ICT not only assist in passing on old content in a new or novel way - but it also helps in teaching new contents in new ways. In addition to ICT focus on enhancing education; it should also help in increasing the general activities of teaching and learning in regards to efficiency and effectiveness.

ICT is also defined for learning as the adoption of technology to enhance education; and his study further supported that it is a systematic, repetitive process for designing and developing instruction or trainings adopted for enhancing performance. Researches on ICT, always has optimistic outcomes. ICT majorly concentrates on enhancing the effectiveness and efficiency of conventional practice of teaching and learning process and this leads to educational change. Also, [12] stated that instructional technologist cannot again see ICT tools as just any piece or tool of equipment and engagement. If these technologist are focused on analyzing attentively about teaching and learning, then ICT tools will have an impact to the design of ICT based learning environment in order to provide a novel approach on the nature of education and its objectives.

Modern ICT tools are adopted by thousands of institutions, and they are handy and most for free, attractive and exciting to adopt, which makes them necessarily important to be incorporated into education and most especially to enhance teaching/learning process. Most researchers proposed that ICT tools advocates for constructivist perspectives in education and that it has the possibility of ubiquitous learning compared to what is previously witnessed in the conventional educational environments [13], [14, [15]. Most literature works have exposed usefulness of ICT tools for educational purposes [16]. These also combined its use in enhancing learners' discussions for improving learning stimuli and experience; and taking individualized subject materials [17], [18], [19]. Moreover, some researchers stated that ICT educational tools and activities are very useful for improving learners' collaborative and cooperative skills [20], [21], [22].

Furthermore, by adopting ICT educational tools, most especially the socializing tools, such wikis, blogs and social networking sites, learners are majorly seen to be more active members in creating their own learning pace, personal experience and idea [23]. ICT tools enables learners to make themselves openly noticeable, since they have the freedom to publish their content, work, material online through wikis and blogs. On the other hand, adopting ICT educational tools can further build learners stimulus, motivation and support their focus to details, which will further lead to a total improved quality of work. In [24], it is notified that when learners publish their content, materials or work online for numerous viewers or audiences, such works most times are firsthand, captivating and interesting for others to view. This leads to a more proper evaluation from colleagues and instructors. Majority of experts in educational line agreed that if it is properly utilized, ICT possesses a huge capacity to increase instructional and learning aid to organize work force opportunities.

\subsection{Related Research}

This section gives a review of related studies that have examined students' awareness towards the use of ICT tools in their learning which have been discussed in past research works. Various researches reveal that learners, who are adopted by technological facilities regularly, display greater learning achievements than the ones that are not adopted. In [25], it is discovered in his study that 75 researches commented on the following outcomes: Learners that adopted computers in their courses like math, natural science, and social science were marked considerably greater on assessments in these courses. Learners that adopted simulation software in science also scored greater mark. The discoveries also showed that primary school learners that adopted computer software in reading were marked considerably greater on reading scores.

The study in [26] described that digital natives have expanded their whole lives bounded by technologies like computers, mobile phones and other tools of digital era. He further stated that the digital beliefs and surroundings, which the natives grew up in, had transformed the manner the way they perceive in education. Digital natives depend greatly on communicating and being interactive through technological tools in education to gathered information. Nevertheless, their perceptions are in disagreement with the suggestions of [27] that efficient teaching plan by the instructor other than technology is a proper way of attaining superior education.

In the research of [28] with 94 primary students in four Midlands colleges showed the continuous impact of home, institutions and ways of technological tool adoption in teaching and learning. The degree of outside college adoption of technological tools was also viewed as pertinent. In [29], it is established a research of 'action relating to reasons' (ICT reception) to examine the purpose of why most individuals adopt PCs, and to 
analyze their perception to them. They have experimented technology acceptance (TAM) model with 107 adult users that had been adopting an administrative system for 14 weeks. They discovered that individual's PC usage were connected to their purpose of using PCs, and perceived importance were also powerfully connected to this purpose.

Since the old days of adopting small microcomputers, there have been statements of learners remaining quite longer on the assignment, growing their dedication to education, attaining more via the usage of PCs and also being passionate about computer usage in their classes.

In [30], it is analyzed that learners are usually more 'on task' and show more optimistic moods while they are dealing with the technology-related tasks related. Moreover, in [31] is also stated that "... learners with little levels of inspiration and moods of doubt concerning their learning abilities can display a more optimistic conduct during teaching by adopting PCs than during conventional teaching".

On the other hand, [32] unveiled a range of optimistic influences of ICT tools on learners, together with improved capability to work individually, improved self-confidence in interacting with colleagues outside the college and family spheres, improved appearance at class and improved group activities and collaborative skills. Learners who adopt ICT in college felt more fulfilling in class, they were more inspired to learn and possess high personal-confidence and self-esteem.

It is obvious that via many experimental researches on the concept of using ICT tools in education with the inspirational influence of such tools will have a significant impact on learners' perception to learning and maintains a constructive influence on students' accomplishment.

\section{Methodology}

This section focuses on discussing the approaches that will be adopted in carrying out the investigation of the topic case; which entails analyzing undergraduate EMU IT students' awareness on the use of ICT educational tools and the effectiveness of such tools. Detailed explanation will be given about research design, sample data, data collection, techniques and data analysis.

Quantitative and qualitative approaches are adopted in the study to allow for the collection of data on the population of IT department undergraduate students of EMU in Northern Cyprus through a questionnaire during the spring semester of 2014-2015. The questionnaire in [33] was adopted for this study and distributed to 140 undergraduate IT students in the paper-based format to obtain the needed data for the research goal. However, only 120 of those students could fill out the questionnaire and the remaining 20 copies were unreturned due to factors concerned with the participants; and also, five interview questions were asked to 17 respondents and recorded during data collection process. The questionnaire was designed into three sections that are related to the research questions of the study in which the first part comprises the demographics, the second part contains 25 questions for analyzing the purpose and level of skills of using ICT tools, while the third part of the questionnaire adopts five-point Likert scale (1: strongly disagree; 2 : disagree; 3 : neutral; 4: agree; 5: strongly agree) to measure the degree of responses of the participants on the usefulness of ICT tools in their learning processes. The demographic information of the participants is given in Table 1.

Table 1. Demographic Information of the Participants

\begin{tabular}{|l|l|c|c|}
\hline & & Frequency & $\begin{array}{c}\text { Percentage } \\
(\mathbf{\%})\end{array}$ \\
\hline Gender & Male & 72 & 60.0 \\
& Female & 48 & 40.0 \\
\cline { 2 - 4 } & Total & $\mathbf{1 2 0}$ & $\mathbf{1 0 0 . 0}$ \\
\hline \multirow{2}{*}{ Age } & $20-25$ & 44 & 36.7 \\
& $25-35$ & 48 & 40 \\
& 35 and older & 28 & 23.3 \\
\cline { 2 - 4 } & Total & $\mathbf{1 2 0}$ & $\mathbf{1 0 0}$ \\
\hline Class & 1 & 42 & 35.0 \\
Level & 2 & 46 & 38.3 \\
& 3 & 27 & 22.5 \\
& 4 And Higher & 5 & 4.2 \\
\cline { 2 - 4 } & Total & $\mathbf{1 2 0}$ & $\mathbf{1 0 0}$ \\
\hline
\end{tabular}

As it is shown in Table 1, out of 120 students of the research group; 72 of them were female students $(60 \%)$ and the remaining 48 were male students $(40 \%)$. Moreover, $36.7 \%$ of the sample group's age range was between $18-20,40 \%$ of their age range was between $21-22$ and the remaining $23.3 \%$ of the group was at the range of 23 and older age. Also, according to their years of studies, $35 \%$ of the research group were 1st year undergraduate students, $38.3 \%$ of them were 2 nd year undergraduate students, $22.5 \%$ of them were 3 rd while the remaining $4.2 \%$ were 4 th year undergraduate students as of the time the study was conducted. 
It is worth to mention that the collected data were arranged, further compiled via the Statistical Package for the Social Sciences (SPSS). The gathered data were further be analyzed according to a descriptive statistics in determining the demographic profiles of the participants and for the statistical points of the instrument items; t-test and ANOVA analysis were conducted for determining the correlation significance amongst variables like age, gender and class level.

\section{Findings and Discussions}

This section focuses on the analyzing and interpreting of gathered data for investigating the awareness of EMU IT undergraduate students on the use of ICT tools and their usefulness. Moreover, the existence of any relationship between and amongst their awareness based on their age, gender and class level were also examined in this section. a. The percentage and significant level of skills and the level of purpose on the use of ICT tools by EMU undergraduate IT students:

The analysis of students' general skill levels on the usage of ICT tools are given in Table 2. The first part of the questionnaire, which includes 25 questions, was used to analyze the students' level of skills based on five Likert-scale (1: not skilled at all; 2: not very skilled; 3: neutral; 4: skilled; 5: very skilled).

Table 2. Students' General Skill Levels on The Usage of ICT Tools

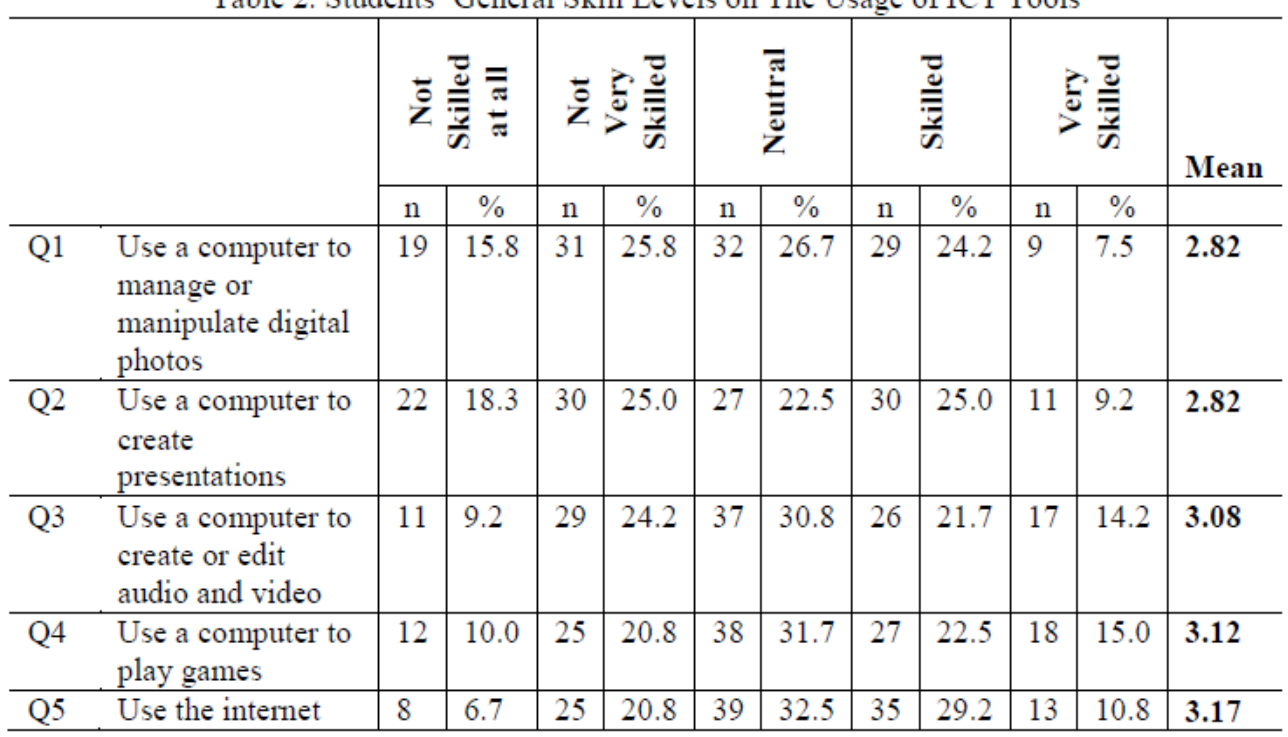




\begin{tabular}{|c|c|c|c|c|c|c|c|c|c|c|c|c|}
\hline & $\begin{array}{l}\text { web or a LAN to } \\
\text { play network } \\
\text { games }\end{array}$ & & & & & & & & & & & \\
\hline Q8 & $\begin{array}{l}\text { Use the web to } \\
\text { look up reference } \\
\text { information }\end{array}$ & 13 & 10.8 & 27 & 22.5 & 36 & 30.0 & 29 & 24.2 & 15 & 12.5 & 3.05 \\
\hline Q9 & $\begin{array}{l}\text { Use the web for } \\
\text { pastimes }\end{array}$ & 8 & 6.7 & 21 & 17.5 & 29 & 24.2 & 37 & 30.8 & 25 & 20.8 & 3.42 \\
\hline Q10 & $\begin{array}{l}\text { Use the } \\
\text { web/internet to } \\
\text { send or receive } \\
\text { email }\end{array}$ & 10 & 8.3 & 31 & 25.8 & 37 & 30.8 & 26 & 21.7 & 15 & 12.5 & 3.07 \\
\hline Q11 & $\begin{array}{l}\text { Use the } \\
\text { web/internet for } \\
\text { instant } \\
\text { messaging/chat }\end{array}$ & 5 & 4.2 & 25 & 20.8 & 35 & 29.2 & 38 & 31.7 & 17 & 14.2 & 3.31 \\
\hline Q12 & $\begin{array}{l}\text { Use the web to } \\
\text { build and maintain } \\
\text { a website }\end{array}$ & 9 & 7.5 & 17 & 14.2 & 35 & 29.2 & 40 & 33.3 & 19 & 15.8 & 3.36 \\
\hline Q13 & $\begin{array}{l}\text { Use social } \\
\text { networking } \\
\text { software on the } \\
\text { web }\end{array}$ & 10 & 8.3 & 19 & 15.8 & 29 & 24.2 & 36 & 30.0 & 26 & 21.7 & 3.41 \\
\hline Q14 & $\begin{array}{l}\text { Use the web to } \\
\text { download } \\
\text { podcasts }\end{array}$ & 5 & 4.2 & 20 & 16.7 & 34 & 28.3 & 37 & 30.8 & 24 & 20.0 & 3.46 \\
\hline
\end{tabular}


To analyze the students' level of skills on the usage of ICT tools, 25 questions at the first part of questionnaire were used. The obtained results shows that $10 \%$ of the EMU IT students are "very skilled" in the use of ICT tools in which $45 \%$ of the students are "skilled" while $30 \%$ are neutral and 15\% lies in the range of "not skilled" and "not very skilled at all". Moreover, the individual mean responses regarding to Q1 up to Q14 are below the average mean of 3.47 which shows that not all EMU IT undergraduate students are "very skilled" in the use of ICT tools, thus majority of them lies on the "neutral" scale and also on the "not very skilled" scale of using ICT tools, especially for the activities of managing/manipulating digital photos, creating presentations, editing audio/video, using web to look up reference information and sending/receiving e-mail through web/internet.

Table 3. illustrates the analysis of the students' awareness on the use of ICT tools regarding to the gender and the relationship between their genders on to the use of ICT tools.

Table 3. Students' Awareness on The Use of ICT Tools Regarding to Their Gender

\begin{tabular}{|c|c|c|c|c|c|}
\hline & & Gender & Mean & $\begin{array}{l}\text { Std. } \\
\text { Div. }\end{array}$ & $\begin{array}{l}\text { Sig } \\
\text { Diff. }\end{array}$ \\
\hline \multirow[t]{2}{*}{ Q16 } & \multirow{2}{*}{$\begin{array}{l}\text { Use the web to share photographs or other digital } \\
\text { material }\end{array}$} & Male & 1.57 & .499 & \multirow[t]{2}{*}{.032} \\
\hline & & Female & 1.67 & .476 & \\
\hline \multirow[t]{2}{*}{ Q17 } & \multirow[t]{2}{*}{ Use the web to make phone calls } & Male & 1.56 & .500 & \multirow[t]{2}{*}{.017} \\
\hline & & Female & 1.67 & .476 & \\
\hline \multirow[t]{2}{*}{ Q18 } & \multirow[t]{2}{*}{ Use the web for web conferencing } & Male & 1.46 & .502 & \multirow[t]{2}{*}{.029} \\
\hline & & Female & 1.65 & .483 & \\
\hline \multirow[t]{2}{*}{ Q22 } & \multirow{2}{*}{$\begin{array}{l}\text { Use the web to contribute to the development of a } \\
\text { wiki }\end{array}$} & Male & 1.47 & .503 & \multirow[t]{2}{*}{.049} \\
\hline & & Female & 1.63 & .489 & \\
\hline
\end{tabular}

The relationship between students' awareness with respect to their genders regarding to the use of ICT tools is analyzed through the first part of the questionnaire that includes 25 questions. As shown in Table 3 , gender is a dependable factor on the usage of ICT tools for Q16, Q17, Q18 and Q22 in which all have significant outcomes lower than the significant point set for this study (i.e. $p<0.05$ ). Those four questions is about $16 \%$ of the total questions that cover the areas of using ICT tools for sharing photographs, making phone calls, for web conferencing and for the development of wiki, invariably, shows that male and female use of ICT tools.

In addition, the average mean of male and female students by considering all 25 questions are calculated as 1.48 and 1.53 , respectively. So, it can be concluded that as $60 \%$ of the male and $24 \%$ of the female students' responses are above their own average, undergraduate male students of IT department in EMU uses ICT tools more than female students on general level of ICT usage. Moreover, in a similar study, it is discovered that ICT tools are used less by female compared to male students and the male students uses ICT tools more regularly, in several settings and have larger experience of various computer software [34]. However, it is worth to mention that throughout the data analysis, no significance differences were obtained regarding to the students' age and class-level in which the topic related opinions of some students are given below:

“...ICT gadgets are at every ones disposal, both old and young. It depends on what tools you master, not what age you become..."

“...Age doesn't make one knowledgeable on being professional in handling a particular instrument of technology; a student becomes better when he practices a lot on that particular tool..."

"...I think that students of different class should have the same skill level set when it comes to using educational ICT tools, I believe that it is not much of a difference when it comes to ICT tool usage in all courses and IT classes..."

b. The significant difference on the awareness level on the use of ICT tools by EMU undergraduate IT students according to their gender, age and class level: 
Table 4. illustrates the general level of purpose of using ICT tools in students' learning process by examining their mean responses.

Table 4. Purpose Level of Using ICT tools in Education

\begin{tabular}{|c|c|c|c|c|c|c|c|c|}
\hline & & \multicolumn{2}{|c|}{ 홀 } & \multicolumn{2}{|c|}{ 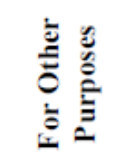 } & \multicolumn{2}{|c|}{ 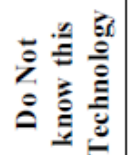 } & \multirow{2}{*}{ Mean } \\
\hline & & $\mathrm{n}$ & $\%$ & $\mathrm{n}$ & $\%$ & $\mathrm{n}$ & $\%$ & \\
\hline Q3 & $\begin{array}{l}\text { Use a computer to create or edit audio } \\
\text { and video }\end{array}$ & 56 & 46.7 & 64 & 53.3 & - & - & 1.53 \\
\hline Q4 & Use a computer to play games & 56 & 46.7 & 64 & 53.3 & - & - & 1.53 \\
\hline Q9 & Use the web for pastimes & 56 & 46.7 & 63 & 52.5 & 1 & .8 & 1.54 \\
\hline Q10 & $\begin{array}{l}\text { Use the web/internet to send or receive } \\
\text { email }\end{array}$ & 58 & 48.3 & 62 & 51.7 & - & & 1.52 \\
\hline Q11 & $\begin{array}{l}\text { Use the web/internet for instant } \\
\text { messaging/chat }\end{array}$ & 53 & 44.2 & 67 & 55.8 & - & - & 1.56 \\
\hline Q13 & $\begin{array}{l}\text { Use social networking software on the } \\
\text { web }\end{array}$ & 53 & 44.2 & 67 & 55.8 & - & - & 1.56 \\
\hline Q14 & Use the web to download podcasts & 50 & 41.7 & 70 & 58.3 & - & - & 1.58 \\
\hline Q16 & $\begin{array}{l}\text { Use the web to share photographs or } \\
\text { other digital material }\end{array}$ & 47 & 39.2 & 73 & 60.8 & - & - & 1.61 \\
\hline Q17 & Use the web to make phone calls & 48 & 40.0 & 72 & 60.0 & - & - & 1.60 \\
\hline Q18 & Use the web for web conferencing & 56 & 46.7 & 64 & 53.3 & - & - & 1.53 \\
\hline Q22 & $\begin{array}{l}\text { Use the web to contribute to the } \\
\text { development of a wiki }\end{array}$ & 56 & 46.7 & 64 & 53.3 & - & - & 1.53 \\
\hline Q25 & $\begin{array}{l}\text { Use a mobile phone to send or receive } \\
\text { email }\end{array}$ & 58 & 48.3 & 62 & 51.7 & - & - & 1.52 \\
\hline
\end{tabular}

From the Table 4 above, $50 \%$ of the general responses show that ICT tools were actually used for learning purpose, and the rest were used for other purposes (i.e. sharing photographs, instant messaging, and making phone calls through the web/internet). Moreover, the average mean of the total responses is 1.51 in which only $48 \%$ of the individual mean scores are above the mean; hence, it can be concluded that there are not too much difference on the students' purpose of using ICT tools for their learning or other purposes. It is worth to mention that, in [35] it is obtained a similar finding which has shown that the ICT has most times been adopted for other purpose other than learning by students of colleges. The topic related opinions of some students are given below:

“...I cannot imagine myself a day without using the internet to interact with friends..."

“...ICT tools are very important especially during communication and learning, and it sometimes save money and time..."

c. The awareness level of EMU undergraduate IT students on the usefulness of ICT tools in their learning process according to their gender and class level:

From the analyses results, which are obtained through the gathered data by using the third part of the questionnaire, it is observed that more than $75 \%$ of the students have a positive attitude towards the usefulness of ICT tools in their general learning process. The topic related opinions of some students that are obtained through the conducted interview are given below:

"... of course, I don't think that any course can survive without the inclusion of technology into the course content, I believe that such class would be boring and activities would be uninteresting..."

“...ICT helps me to understand my work easier, and I feel happy any time we have to do practical courses that involve ICT tools, this makes me so active in class..."

"...it is the love of operating IT tools and its general importance to the world that made him chooses IT department..."

On the other hand, although the analyses showed that there are no significance differences on the awareness level of students on the usefulness of ICT tools in their learning process regarding to their gender; significance differences were obtained on their awareness level regarding to their class level. Table 5 illustrates the students' awareness level on the usefulness of ICT tools in their learning. 
Table 5. The Students' Awareness Level on The Usefulness of ICT Tools in Their Learning Process

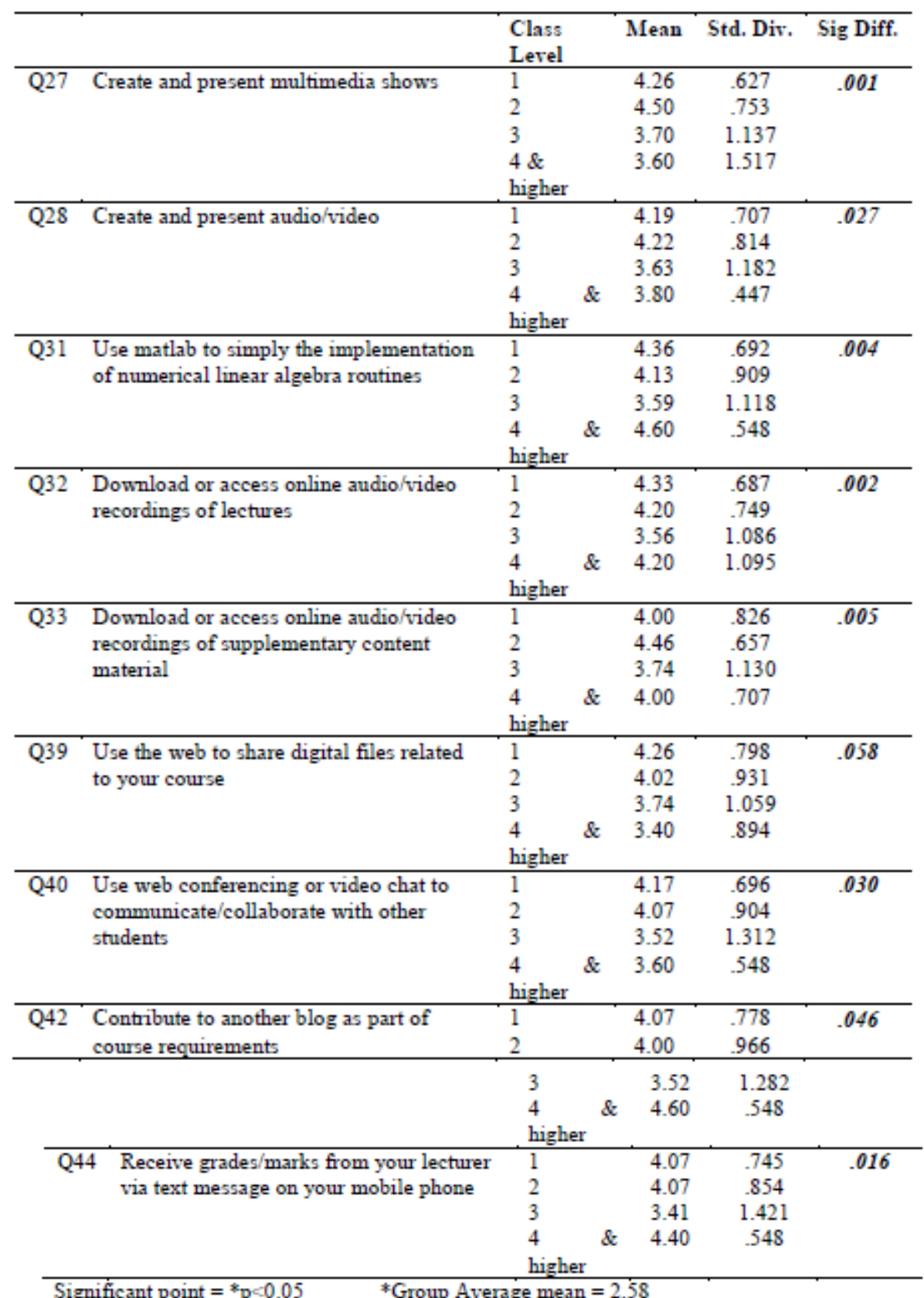

As shown in Table 9, Q27, Q28, Q31, Q32, Q33, Q39, Q40, Q42, and Q44 carries a p value lower than the significant point of 0.05 . This statistically proves that $61.9 \%$ of the entire questions have a significant difference on the students' awareness level of the usefulness of ICT tool in their learning process regarding to their class level. The group average mean of 2.58 , appears not to be in range around the individual mean scores for each questions. Hence, this clearly proves that the absence of mean clusters around the average mean supports the significant differences on awareness of usefulness of ICT tools in education regarding to the class level of the students. Moreover, the topic related opinions of some students that are obtained through the conducted interview are given below:

“...I feel like quitting IT department most especially when I am about to enter my programming class not to talk of the exam, to me it is of no importance and makes my studies hard and uninteresting, though I would have loved it if it is easier..."

"...I am in my third year now and I still cannot boast of a single sophisticated ICT tools I can handle properly, how I wish everything is just theoretical and not practical at every point". He further states that "elearning would have been of good benefits to me if it is practiced in my department, but since it is not, it is useless to me within the school setting unless for home activities..." 
“...I would have failed woefully if not for the help of most ICT tools adopted which make academics faster and easier for me..."

"...all the courses I took during the spring semester that has to do with ICT activities where all distinctions, because it took my time and finally paid me off at the end..."

\section{Conclusion}

The regular growth of global access, ease of use, resilience and functionality of ICT tools have turned them to become attractive and interesting as flexible educational tools to be used in educational institutions. Usefulness of ICT tools for educational purposes gives the advantage of enhancing learners' knowledge, improving learning stimuli and experience Also, usage of ICT tools in education and activities are very useful for improving learners' collaborative and cooperative skills. Teaching and learning scene is the most important area for technology application. Adoption of various ICT tools has been unavoidable for learners in learning process. Through adopting novel ICT tools, learners can collect their expected data in a short range of time. Learners can reach and distribute electronic information, for example, e-journals, e-resources and can develop their learning ability through various newer ICT patterns of wireless connections, web, search sites, databases and web technologies.

In this study, the awareness of IT department undergraduate students of EMU in Northern Cyprus through a questionnaire during the spring semester of 2014-2015 has been analyzed. The awareness of undergraduate students has been assessed on the use of ICT tools and their usefulness in education according to gender, age and class level of students. The results of the study showed that the purpose for which ICT tools is used is majorly for learning purpose and the results also proved that general awareness of EMU IT students on the use of ICT tools is relatively very high, and also that students are moderately skilled for the abilities that is needed for able to use such tools in their learning process. Its worth to mention that, although the data analysis indicated that there is significant differences on the male and female undergraduate EMU IT students' awareness regarding to their gender on the use of ICT tools, no significance differences were obtained regarding to the students' age and class-level.

From the analyses through the gathered data by using the questionnaire, it is observed that more than $75 \%$ of the students have a positive attitude towards the usefulness of ICT tools in their general learning process. Although the analyses proved that there are no significance differences on the awareness level of students on the usefulness of ICT tools in their learning process regarding to their age and gender; significance differences were obtained on their awareness level regarding to their class level.

\section{References}

[1]. M. Desai, J. Hart, and T. Richards, E-learning: paradigm shift in education, Education, 129(2), 2008, $327-334$.

[2]. J. Guilar and A. Loring, Dialogue and community in online learning: lessons from Royal Roads University. Journal of Distance Education, 22(3), 2008, 19-40.

[3]. T. Newby, D. Stepich, J. Lehman, and J. Russell, Instructional technology for teaching and learning: designing instruction, integrating computers, and using media (Columbus, OH: Prentice-Hall, 2000).

[4]. P. Furr, R. Ragsdale, and S. Horton, Technology's non-neutrality: past lessons can help guide today's classrooms, Education \& Information Technologies, 10(3), 2005, 277-287.

[5]. M. Watson, (1998). Blame the Technocentric artifact! What research tells us about problems inhibiting teacher use of IT, in G. Marshall, \& M. Ruohonen (Eds.), Capacity Building for IT in Education in Developing Countries, (1998), 185-192.

[6]. E. Pedretti, J. Mayer-Smith, and J. Woodrow, Closing of the gender gap in technology enriched science education: a case study. Computers \& Education, 35(1), 2000, 51-63.

[7]. A. Heide, and D. Henderson, Active learning in the digital age classroom, (Heinemann, 2001).

[8]. R. Kumar, and A. Kaur, Internet and its use in the engineering colleges of Punjab, India: a case study. Webology, 2(4), $2005,1-22$.

[9]. M. Cross, and F. Adam, ICT policies and strategies in higher education in South Africa: national and institutional pathways. Higher Education Policy journal, 20 (1), 2007, 73-95.

[10]. F. Lawrenz, A. Gravelu, and A. Ooms, Perceived helpfulness and the amount of technology in science and mathematics classes at different grade levels, School Science and Mathematics, 106(3),2006, 133-139.

[11]. U. Eric, S. Drier, S. Harper, and M. A. Timmerman, Promoting appropriate uses of technology in teaching preparation, Contemporary Issues in Technology and Teacher Education, 1(1), 2000, online serial.

[12]. T. OShea, and J. Self, Learning and teaching with computers. (Brighton: Harvester Press, 1983).

[13]. S. Hamid, J. Waycott, S. Kurnia, and S. Chang, S, An empirical study of lecturers' appropriation of social technologies for higher education. Australasian Journal of Educational Technology, 30(3), 2014, 295-311.

[14]. S. Brown, From VLEs to learning webs: the implications of Web 2.0 for learning and teaching. Interactive Learning Environments. 18(1), 2010, 1-10.

[15]. C. McLoughlin, and M. Lee, Social Software and Participatory Learning: Pedagogical Choices with Technology Affordance in the Web 2.0 era, Proc. The Ascilite Conference, Singapore, 2008, 664-675.

[16]. C. Crook, T. Fisher, R. Graber, C. Harrison, and C. Lewin, Implementing Web 2.0 in secondary schools: impacts, barriers and issues, 2008.

[17]. R. Chen, P. Hwang, T. Wu, M. Huang, and T. Hsueh, Assessment of implementing a digital game-based learning system over Facebook, Proc. 11th IEEE International Conference on Advanced Learning Technologies, 2011, 620 -621.

[18]. P. Racthman, and D. Firpo, Using social networking technology to enhance learning in higher education: A case study using Facebook, Proc. 44th Hawaii International Conference on Systems Science, Hawaii, USA, 2011, 1-10. 
[19]. S. Griffith, and L. Liyanage, An introduction to the potential of social networking sites in education, Proc. Second Emerging Technologies Conference, Australia: Wollongong, 2008, 76-81.

[20]. K. Pursel, and H. Xie, Patterns and pedagogy: exploring student blog use in higher education, Contemporary Educational Technology, 5(2), 2014, 96-109.

[21]. E. Tay, and M. Allen, Designing social media into university learning: Technology of collaboration or collaboration for technology?, Educational Media International, 48(3), 2011 151-163.

[22]. R. Hall, and M. Hall, Scoping the pedagogic relationship between self-efficacy and Web 2.0 technologies. learning, media and technology, 35(3), 2010, 255-273.

[23]. J. Preece, and B. Shneiderman, The reader-to-leader framework: motivating technology-mediated social participation. AIS Transactions on Human-Computer Interaction, 1(1), 2009, 13-32.

[24]. W. Rifkin, N. Longnecker, J. Leach, L. Davis, and L. Ortia, Motivate students by having them publish in new media: an invitation to science lecturers to share and test, Proc. The Australian Conference on Science and Mathematics Education: Motivating Science Undergraduates - Ideas and Interventions, Sydney, Australia, 2009, 105 - 111

[25]. A. Kulik, Meta-analytic studies of findings on computer-based instruction, in J.E.L.Baker and H.F.O’Neil (Ed.), Technology Assessment in Education and Training, (Hillsdale, NJ: Lawrence Erlbaum, 1994) 9-33.

[26]. M. Prensky, Digital native, digital immigrants, On the Horizon, 9(5), 2001, 1-6.

[27]. K. Sarfo, and J. Elen, Developing technical expertise in secondary/technical schools: the effect of 4C/ID learning environments, International Journal of Learning Environment,10(3), 2007, 207 - 221.

[28]. S. McNicol, Facilitating student reflection through digital technologies in the iTEC project: pedagogically-led change in the classroom, learning and collaboration technologies, In: Zaphiris P., Ioannou A. (Eds.) Learning and Collaboration Technologies. Technology-Rich Environments for Learning and Collaboration, Lecture notes in computer science, 8524 (Cham, Springer, 2014) 297-308.

[29]. F. Davis, P. Bagozzi., and P. Warshaw, User acceptance of computer technology: a comparison of two theoretical models, Management Science, 35( 982), 1989, 982-1003.

[30]. J. Becta, The secondary school of the future - a preliminary report to the dfee by Becta. 2001 .

[31]. J. Becta, Review of research literature on barriers to the uptake of ICT by teachers, 2004

[32]. S. Harris, Innovative classroom practices using ICT in England, Journal of Computer Assisted Learning, 4 (18), 2002.

[33]. A. Rhema, and I. Miliszewska, Analysis of students' attitude towards e-learning: the case of engineering students in Libya, Informing Science and Technology, 11. 2014, 169-190.

[34]. H. Jorge, R. Gutiérrez, G. García, A. Jorge and B. Díaz, Use of the ICTs and the perception of e-learning among university students: a differential perspective according to gender and degree year group, Interactive Educational Multimedia, 7, $2003,13-28$.

[35]. R. Oliver, The role of ICT in higher education for the 21st century: ICT a change agent for education, Proc. The Higher Education Conf. for the 21 st Century, Curtin, 2003. 